\title{
Geophysical Studies of Wells in the Settlements of Konoplyanka 1 and Konoplyanka 2 (Bronze Age)
}

\author{
Vladislav Noskevich ${ }^{1 *}$, Natalia Fedorova ${ }^{1}$ \\ ${ }^{1}$ Institute of Geophysics Ural Branch of the Russian Academy of Sciences, Amundsen Street 100, 620016, Yekaterinburg, Russia
}

\section{ARTICLE INFO}

Article history:

Received: $23^{\text {rd }}$ March 2021

Accepted: $17^{\text {th }}$ August 2021

DOI: http://dx.doi.org/10.24916/iansa.2022.1.2

\section{Key words}

settlement

well

magnetic survey

GPR

magnetic susceptibility

Bronze Age

South Urals

\begin{abstract}
$A B S T R A C T$
In the South Urals, numerous wells have been found inside dwellings in settlements of the Bronze Age. These features are of great interest, not only because of the artifacts found inside the wells, but also as the first hydrotechnical structures within the territory of northern Eurasia. Geophysical studies were carried out over the area of two Bronze Age settlements: the fortified settlement of Konoplyanka and the unfortified settlement of Konoplyanka 2. A gradient magnetic survey was carried out and settlement plans reconstructed, which formed the basis for the selection of sites for the archaeological excavations. Comparison of geophysical and archaeological results showed that, using magnetic maps, it was possible to accurately reconstruct the plans of ancient settlements and localize the positions of wells. At the excavation site of the settlement of Konoplyanka 1, as a result of the magnetic susceptibility survey, it was established that the edges of the wells were reinforced with a special soil that has higher magnetic properties than the subsoils present. At the excavation site at the settlement of Konoplyanka 2, ground penetrating radar (GPR) prospection of the four wells was carried out, the depth and structural features of these wells being determined. Excavations at two of the wells confirmed the results of the geophysical studies.
\end{abstract}

\section{Introduction}

In modern archaeology, at the initial stage of the search and localisation of ancient monuments, geophysical methods are actively used (Aspinal et al., 2008, Conyers et al., 2016, Scollar et al., 1990). In the Southern Urals, more than 20 fortified settlements of the Bronze Age dating back to the $21^{\text {st }}-18^{\text {th }}$ centuries BC have been discovered (Gening et al., 1992; Zdanovich and Batanina, 2007). The architecture of the settlements is almost completely destroyed, and the earthen walls of the settlements, the ditches and dwelling cavities have been ploughed up. Over the study area of a number of settlements (Arkaim, Kamennyi Ambar, Konoplyanka, Andreevskoe, Sarym-Sakly, Ustye, Zhurumbai, Kuisak, Rodniki, Ulak), a magnetic survey has been carried out, as a result of which the locations of the outer defensive walls and ditches and the walls of buildings have been determined and the plans of settlements reconstructed (Tibelius, 1995; Punegov, 2009; Merrony et al., 2009; Noskevich and Fedorova, 2013; 2020; Hanks et al., 2013; Fornasier et al.,

*Corresponding author. E-mail: ubistu@gmail.com
2014; Bakhshiyev et al., 2018). Inside many dwellings, local magnetic anomalies are clearly distinguishable: created by the remains of wells, utility pits and stoves. Archaeologists can use the obtained information concerning the structure of monuments and their precise referencing and then more purposefully select sites for excavation (Koryakova et al., 2018). The results obtained in the process of such excavations help to increase the reliability of the interpretation of the geophysical anomalies and link them with the site's specific structures.

Extensive excavations were carried out at the Kamenny Ambar settlement and numerous wells were found inside the dwellings. These features aroused great interest: not only because of the artifacts found inside the wells, but also as they were the first hydraulic structures found in northern Eurasia (Koryakova et al., 2019). Epimakhov et al. (2020) presented 44 radiocarbon dates from 18 wells from different eras of the Bronze Age. This settlement functioned for more than 150 years and, based on the materials obtained from the wells, it was possible to establish the absolute age and stages of settlement. It was revealed that most of the wells belong to the Sintashta-Petrovka period, which is characterised 

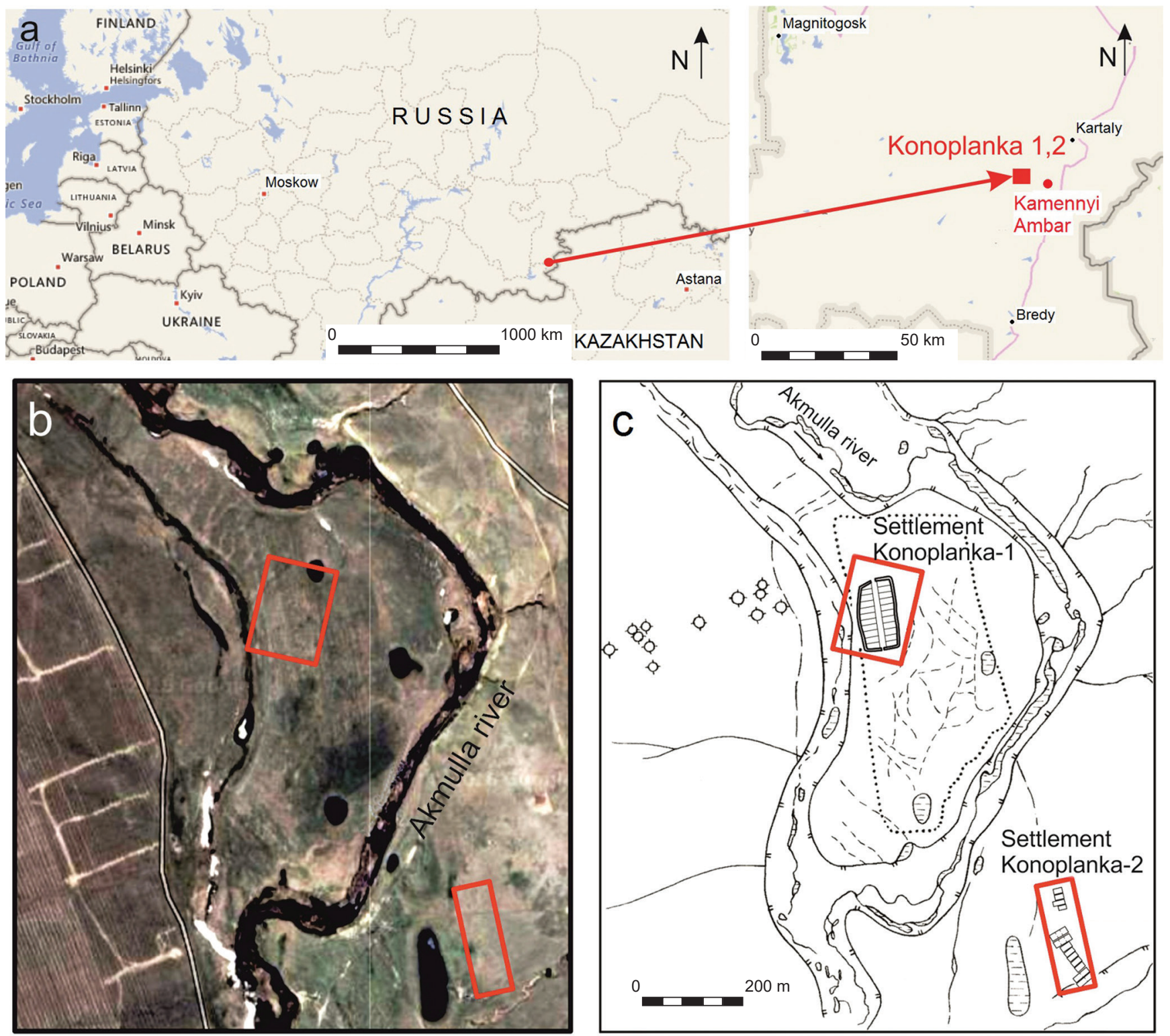

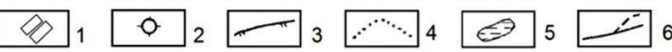

Figure 1. a: Fragment of map of Eurasia, the position of the settlements Konoplyanka 1 and Konoplyanka 2 being marked; b: Present view of the Akmulla river valley; c: Diagram of location of monuments. Magnetic survey areas are shown with red rectangles. 1 - buildings, 2 - burial mounds, 3 - floodplain terrace, 4 - border of arable land, 5 - flooded depressions, 6 - river and streams.

by linearly-located blocks of buildings inside fortified territories. The second period, marked by randomly-located dwellings, is associated with Srubnaya-Alakul artifacts and is represented by only four wells. During this period, a transformation of the architectural tradition took place, with both the layout of the settlement and the construction of the wells being changed.

In the valley of the Karagailly-Ayat River (Chelyabinsk region, Russia), at a distance of about $20 \mathrm{~km}$ from the Kamennyi Ambar settlement, there are other settlements of the Bronze Age: the fortified settlement of Konoplyanka and the unfortified settlement of Konoplyanka 2. The fortified settlement of Konoplyanka (hereinafter referred to as Konoplyanka 1) is located on the banks of the Akmulla river. The settlement was discovered based on the results of interpretation of aerial photographs (Zdanovich and Batanina, 2007). The total area is c. $15,000 \mathrm{~m}^{2}$, and the area inside the fortifications is c. $8400 \mathrm{~m}^{2}$. On the other bank of the river, at a distance of $800 \mathrm{~m}$, there is the unfortified settlement of Konoplyanka 2 (Figure 1b). The settlement was discovered in 1982 (Tarasov, 1983). As a result of archaeological research, 10 shallow dwelling depressions were found on the surface. Seven of them are almost closely adjacent to each other, located in one line along the edge of the coastal terrace in a north-north-west - south-east direction. Three more depressions are located $50 \mathrm{~m}$ to the north. This village is located about $100 \mathrm{~m}$ east of a small lake and $200 \mathrm{~m}$ from the current river bed. 
Agricultural work was carried out in the area of both archaeological sites in the $20^{\text {th }}$ century, and at present, due to many years of ploughing, their structures are practically invisible on the land surface (Figure 1b). Over the area of both these villages we carried out a magnetic survey and reconstructed the plans of the settlements. This paper presents a comparison of the magnetic maps that were produced, with the results of the excavations and geophysical studies of wells found in the dwellings of these settlements.

\section{Geophysical survey technique}

A gradient magnetic survey was carried out on a previously prepared network with an observation step of $0.5 \times 0.5 \mathrm{~m}$. The survey area was divided into squares with sides from 20 to 40 metres. The measurements were made with a complete stop of the device, and the magnetometer sensors were precisely centred over the observation point. The height of the sensors is $0.35 \mathrm{~m}$ and $2.15 \mathrm{~m}$ from the ground. After surveying the squares, the measurement results were combined into a common database. The magnetic anomaly map was constructed as the difference between the measured values of the induction modulus of the geomagnetic field of the lower and upper sensors. The measured data contained a contribution from geological sources; therefore, to isolate anomalies from the walls of dwellings, the long-wave component (more than $10 \mathrm{~m}$ in length) was filtered. Absolute modular magnetometersgradiometers MMPG-1 (Russia), and Navmag SM-5
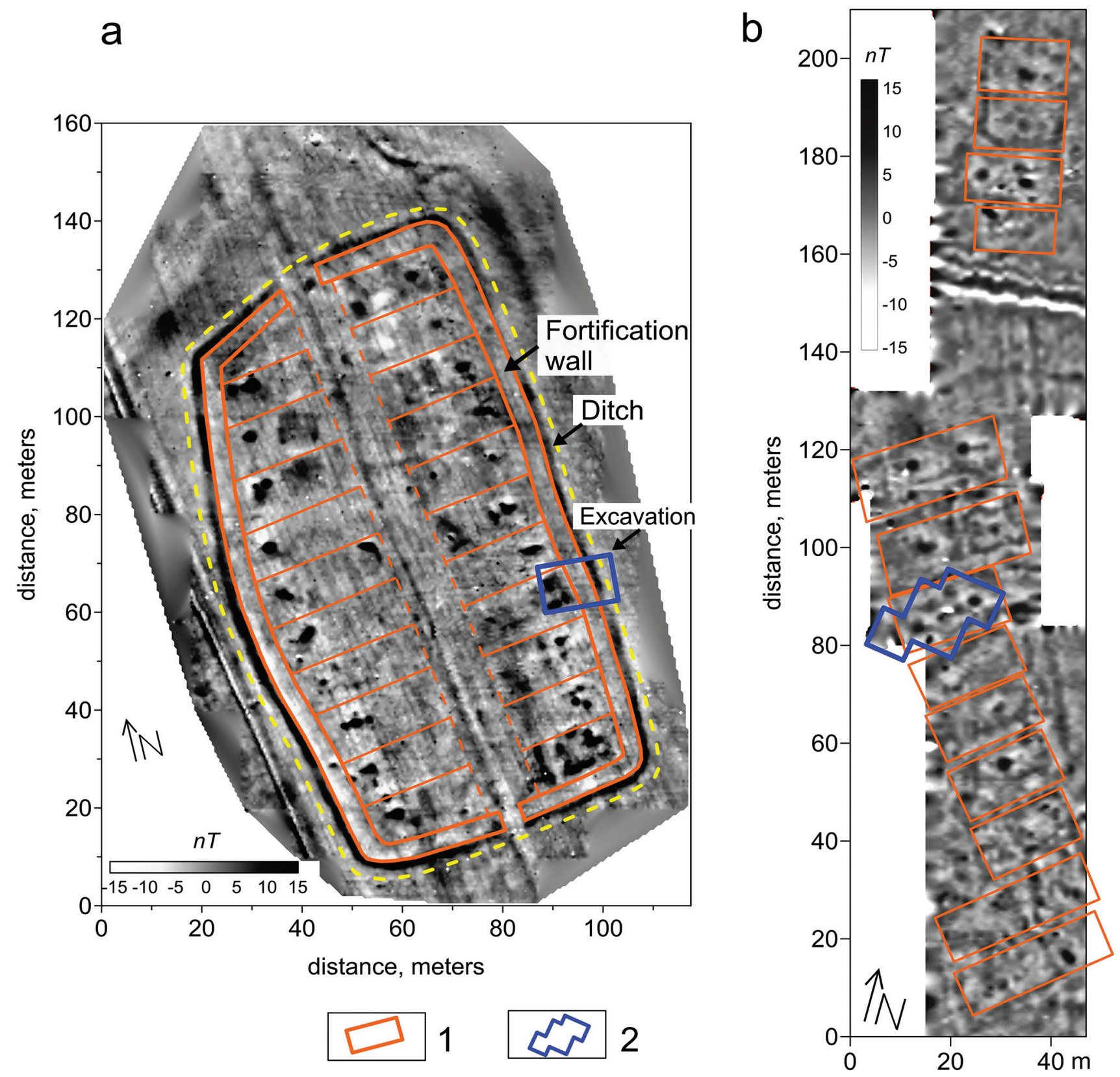

Figure 2. Maps of magnetic anomalies and reconstructed plans of settlements: a: Konoplyanka 1; b: Konoplyanka 2.1 - dwellings, 2 - excavation contour. 
(Canada) were used. The survey error does not exceed \pm 1 nT (Fedorova et al., 2014).

The kappameter surveys are a supplement to magnetic prospection and make it possible to measure the magnetic susceptibility of the soil directly at the archaeological site. This survey was carried out on the walls of the excavation along a network of $0.2 \times 0.2 \mathrm{~m}$ using a PIMV kappameter (St. Petersburg, Russia). The error of a single measurement of the magnetic susceptibility did not exceed \pm 0.0001 units SI.

A topographic survey of relief elevations in the settlements of Konoplyanka 2 was carried out over an area of 55,000 $\mathrm{m}^{2}$. A Sokkia 105 (Japan) total station with an error of 5" was used. For a more accurate localisation of dwelling depressions, the long-wavelength component was filtered and local relief variations were identified. The error in determining the heights of the relief is estimated to be no more than $\pm 0.02 \mathrm{~m}$.

The GPR method is based on the emission of ultrawideband pulses of electromagnetic waves. The peculiarity of the GPR survey is that the antenna emitting electromagnetic waves and the antenna receiving reflected waves are located in the same place. Reflections occur at the interfaces between media with different relative permittivity of soils. At the point of measurement on the radargram along the vertical line, the wave pattern of the reflected waves and time are displayed. We used a grey scale to display the intensity and polarity of the signal (white is the positive amplitude and black is the negative part of the waveform). To switch from the time scale to the depth scale on the sections, the researcher needs to know the speed of the electromagnetic wave, which depends on the relative permittivity of the soil. For the settlement of Konplyanka 2, we used tabular data for dry loams and adopted a dielectric constant of 4 (Finkelshteyn et al., 1976). The GPR survey was carried out with the SIR-3000 (GSSI,
2008) along parallel profiles with a spacing of $0.5 \mathrm{~m}$. After processing and interpolation of reflections along all profiles for the study area, a plan of isolines of depths of reflecting boundaries and a three-dimensional model of underground features were built.

\section{Results of magnetic surveys of settlements}

We carried out magnetic surveys on the site of the fortified settlement of Konoplyanka 1 in 2009-2010 and in 2017 on the site of the open settlement of Konoplyanka 2 (Noskevich and Fedorova, 2013; Fedorova et al., 2018). The resulting magnetic maps and reconstructed settlement schemes are shown in Figure 2. The fortified settlement of Konoplyanka 1 was approximately $150 \times 100 \mathrm{~m}$ in size, enclosed by a wall, a moat and, possibly, an outer rampart. Two passages to the settlement are clearly visible - from the north and from the south. A large number of local magnetic anomalies were found inside the settlement, the most intense of which formed two chains along the western and eastern walls. These anomalies are created by wells, utility pits, and possibly the remains of hearths and stoves inside dwellings. The dwellings are arranged in two rows, with 11 buildings in each row. The width of the buildings, determined by the location of intense local anomalies, is about 10 metres.

The methods developed in magnetometry make it possible not only to find a source's location, but also to obtain information about its shape and depth through the interpretation of magnetic anomalies. Modelling the sources of several local anomalies showed that the depth to the upper edges of the sources is $0.6-1.15 \mathrm{~m}$ (Noskevich and Fedorova, 2013). Consequently, the cultural layer of buildings inside the settlement is at a depth of at least $0.6 \mathrm{~cm}$ from the modern surface. In addition, a number of sources
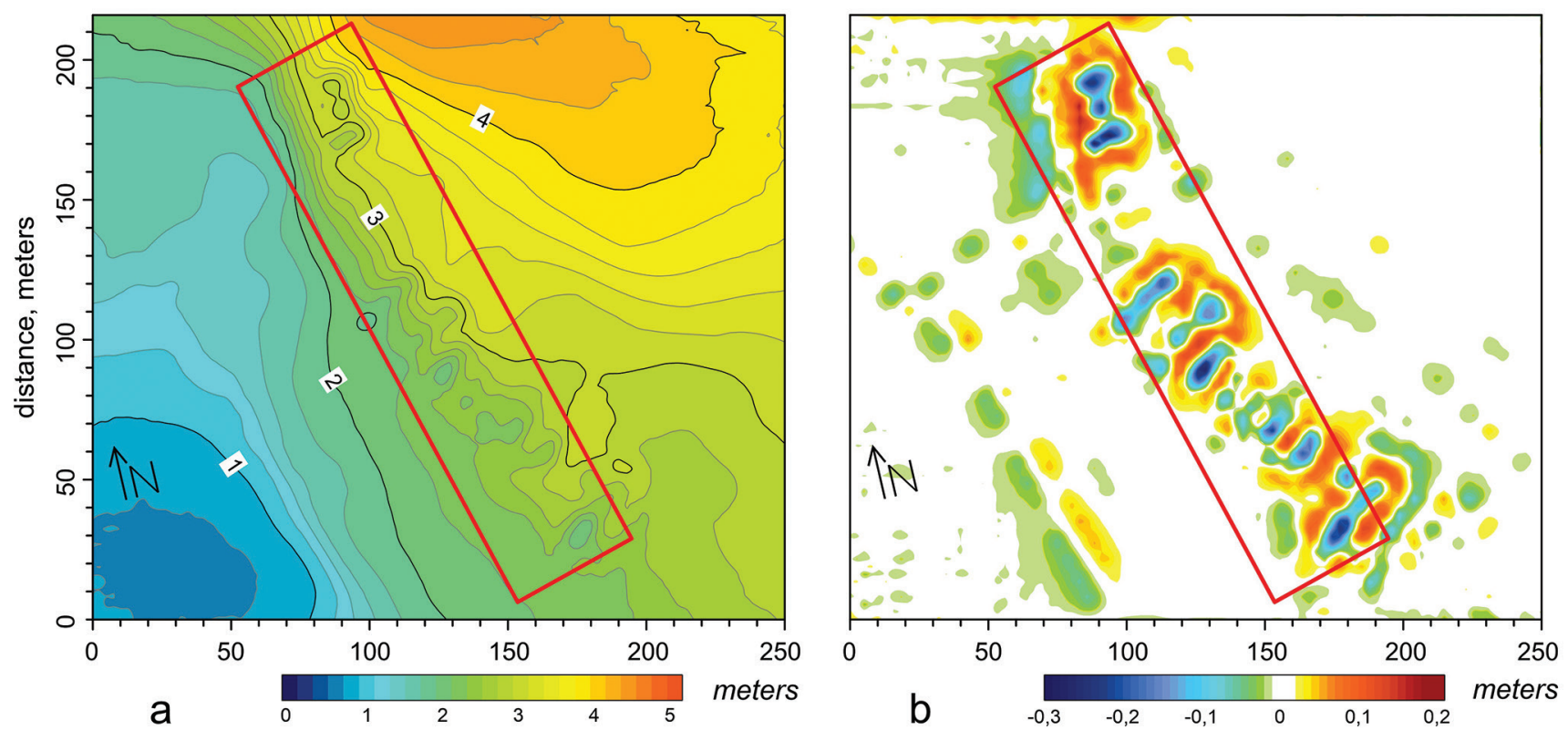

Figure 3. Open village Konoplyanka 2: a: Relief altitudes, b: Local anomalies of the relief. 
of intense local anomalies are elongated vertically to a depth of 2-4 m and, undoubtedly, these anomalies were created by wells. As a result of the interpretation of the linear magnetic anomaly over the section of the western fortification, it was found that the centre of the source is located at a depth of $0.75 \mathrm{~m}$; hence the source is located below the floor level of the house in the settlement. Investigation of the same section of the fortification with the help of GPR received intense reflections of the electromagnetic signal from the defence system at depths of $0.5-2 \mathrm{~m}$. The most intense reflections at a depth of $0.73 \mathrm{~m}$ are associated directly with the defensive wall, and this result does not contradict the data of the interpretation of the magnetic survey. Deeper reflections on radargrams are created by multiple repeated reflections of electromagnetic waves from the boundaries of the ditch. Thus, prior to excavation, geophysical methods were able to trace the position of the defensive wall and its depth relative to the modern surface of the earth and to connect a number of local anomalies with wells.

On the unfortified settlement of Konoplyanka 2, a detailed topographic survey was carried out and local anomalies of the relief were highlighted (Figure 3). As a result, 13 dwelling depressions were discovered, the depth of which varies from 0.1 to $0.4 \mathrm{~m}$. Some depressions consist of 2 or 3 chambers. A magnetic gradiometer survey was carried out over an area of $45 \times 210 \mathrm{~m}$ (Fedorova et al., 2018). Based on the results of this survey, it was possible to identify the boundaries of buildings and reconstruct the settlement plan (Figure $2 b$ ). The number of dwellings turned out to be more than previously assumed based on the results of archaeological research (Tarasov, 1983); in fact, this survey identified 13 houses. Local magnetic anomalies were revealed inside the houses, the intensity of some anomalies reaching 12-15 nT, and, most likely, the anomalies were created by wells and utility pits.

The magnetic survey was continued by the German geophysicist A. Patzelt over an area of 10.4 hectares, as a result of which, $50 \mathrm{~m}$ north of the known features, another

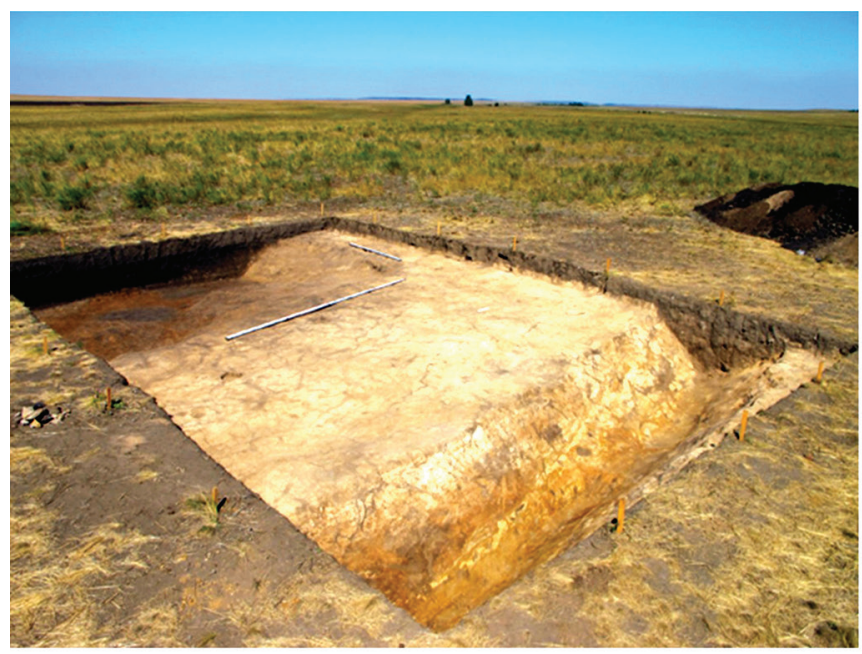

a line of dwellings was discovered that had no visible signs on the surface (Koryakova et al., 2020).

\section{Research at the excavation site of the Konoplyanka 1}

The magnetic maps became the basis for the selection of sites for archaeological excavations. The first excavation site for the Konoplyanka 1 settlement was laid in 2012 by researchers from the Institute of History and Archaeology of the Ural Branch of the Russian Academy of Sciences (Sharapova et al., 2014). A sector of $8 \times 12 \mathrm{~m}$ was chosen in the eastern part of the settlement (Figure 2a). The excavation grid covers a fragment of the enclosure (ditch, wall) and the corner of the dwelling (Figure 4). The thickness of the wall at the level of the subsoil was $4-4.5 \mathrm{~m}$. The ditch in this area is characterised by a not very large difference in depths from $0.4 \mathrm{~m}$ to $1.3 \mathrm{~m}$ and had a width of 2-2.5 $\mathrm{m}$. A residential building adjoins the inner wall of the enclosure, the foundation pit of which is deepened into the subsoil by no more than $0.6 \mathrm{~m}$. A well and utility pit were found in the house.

A fragment of a magnetic map and a plan of the excavation site are shown in Figure 5. In order to show the intensity of magnetic anomalies, we used a colour scale. The boundaries of prehistorical features correspond well to the data of the magnetic map. A large positive anomaly corresponds to the foundation pit of the dwelling, and negative anomalies are located above the walls of both the defensive and separating adjacent houses. Apparently, there was a fire in this house, as a result of which the soil acquired stronger magnetic properties than in the neighbouring dwellings. Two local magnetic anomalies are associated with a utility pit and a well, and the third is observed over a small depression on the floor.

The linear magnetic anomaly is located above the ditch. Excavation studies revealed that in different parts of the ditch the soil differed in its physical properties: at the outer border

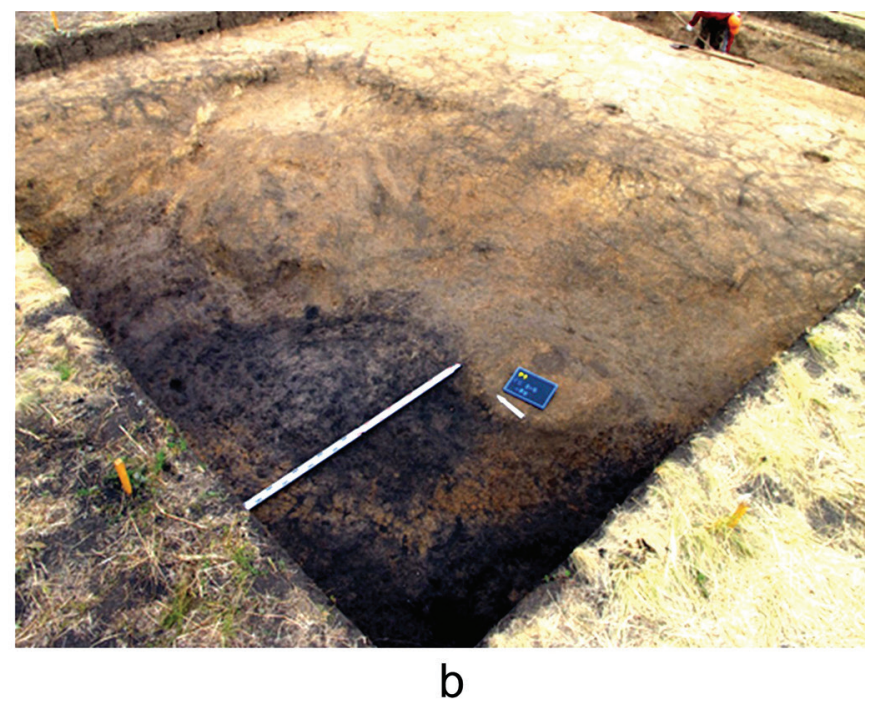

Figure 4. Konoplyanka 1: a: Photograph of the excavation; b: Photograph of the floor of the building. 

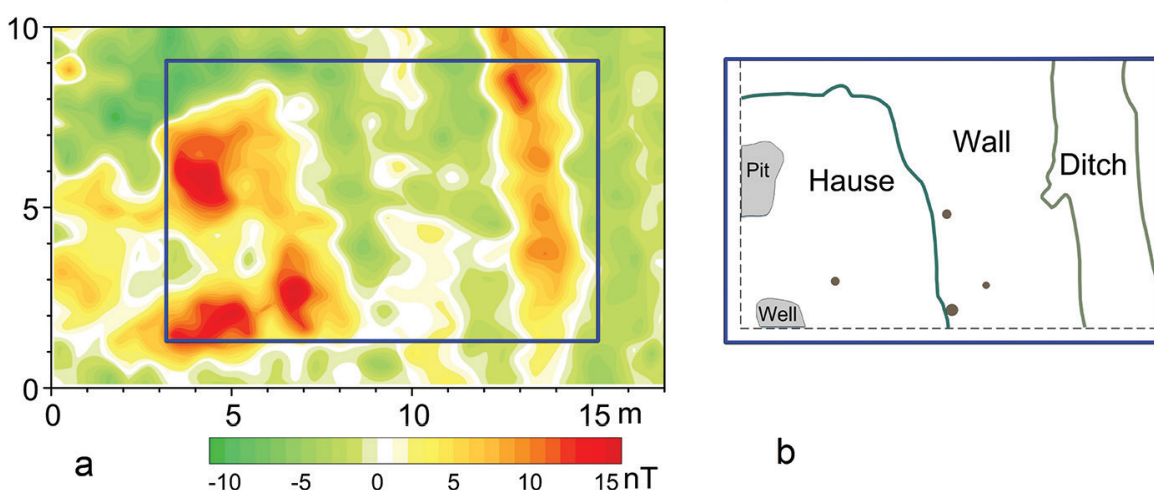

b
Figure 5. a: Part of a magnetic map; b: Excavation plan; after Sharapova et al. (2014). it was loose, and at the inner wall it was very dense and dry (Sharapova et al., 2014). As a result of magnetic surveys at the excavation site of another Bronze Age settlement, Kamennyi Ambar, it was established that an anomaly over the fortification is created from the outer side of the wall and along the edge of the ditch with a layer of $0.3-0.5 \mathrm{~m}$ of light-yellow loam. This material was used to strengthen the outer surface of the soil wall and the ditch up to its bottom part (Epimakhov et al., 2016).

Excavations were laid along the southern and western walls, where the well and the pit were located. The well has the shape of a funnel, the diameter at the surface is more than 2 metres and at depth it is reduced to $0.8 \mathrm{~m}$ (Figure 6a). The bottom of the well was found at a depth of
$2.6 \mathrm{~m}$ from the zero benchmark, the depth of mining in the subsoil being $1.6 \mathrm{~m}$. At present, the well is dry: apparently, the groundwater level was much higher in the Bronze Age. In the photograph can be seen different soil colours, which are caused by the dissolution of magnetic soil minerals by groundwater (Fassbinder, 2015; Jordanova, 2016). Along the western wall of the excavation, the pit is about $2 \mathrm{~m}$ long and about $1.1 \mathrm{~m}$ deep (Figure 7a). Studies of ceramics and stone arrowheads showed that the Konoplyanka 1 monument belongs to the Sintashta-Petrovka culture, and radiocarbon dating established that the settlement functioned in the period 1920-1745 BCE. (Sharapova et al., 2014).

We used the excavation to determine the magnetic properties of the soil. On the profiles of the excavation, intersecting the

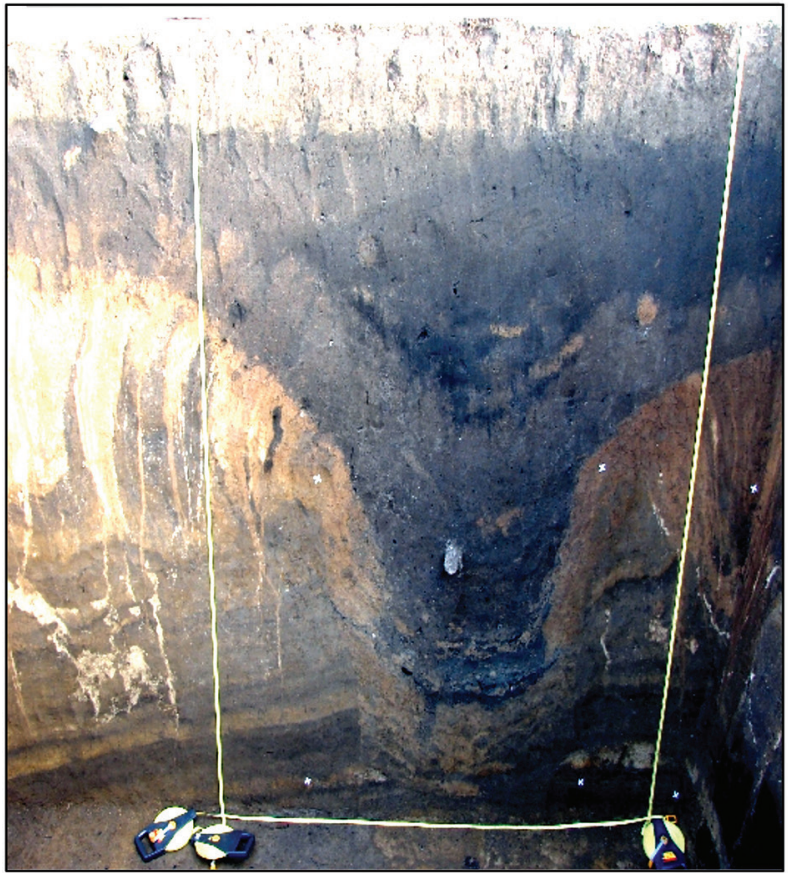

a

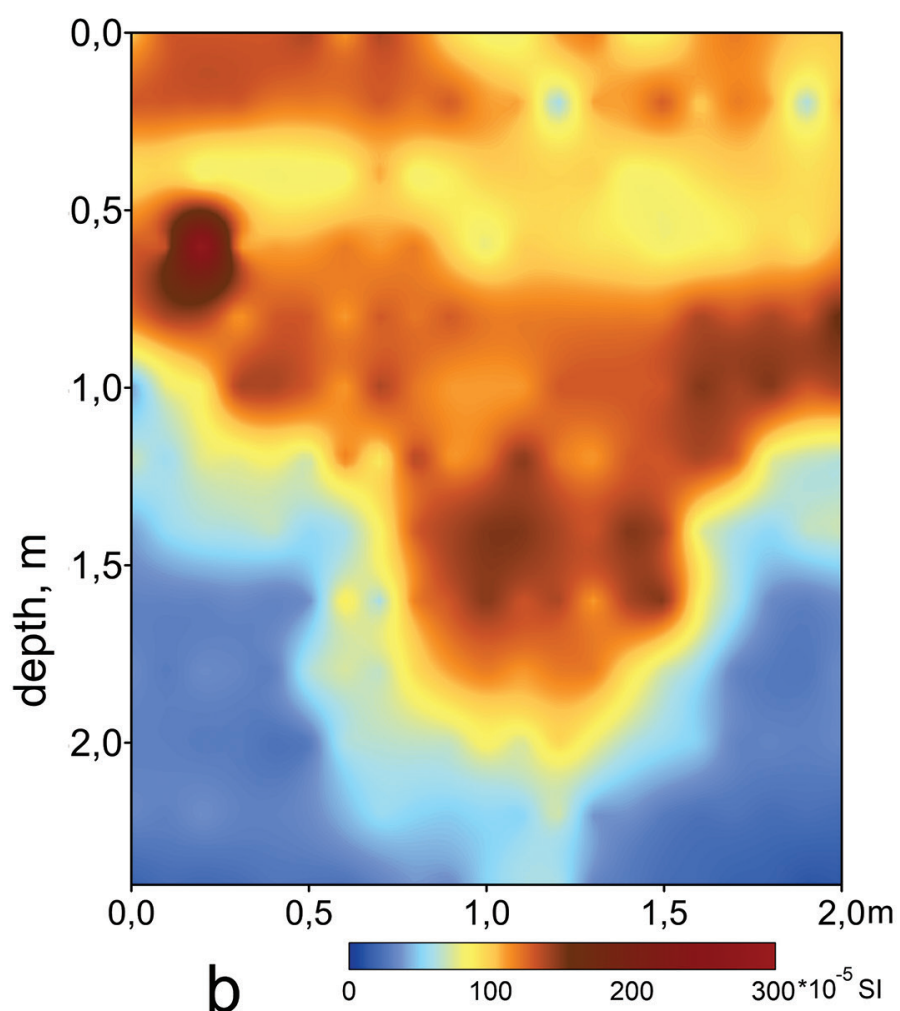

Figure 6. Southern wall of the excavation: a: Photograph of the well; b: Result of the magnetic susceptibility measurements. 


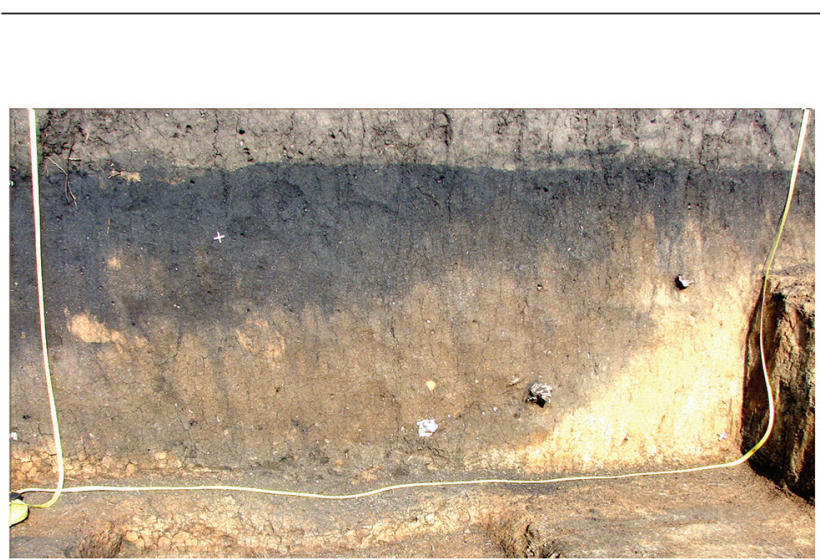

a

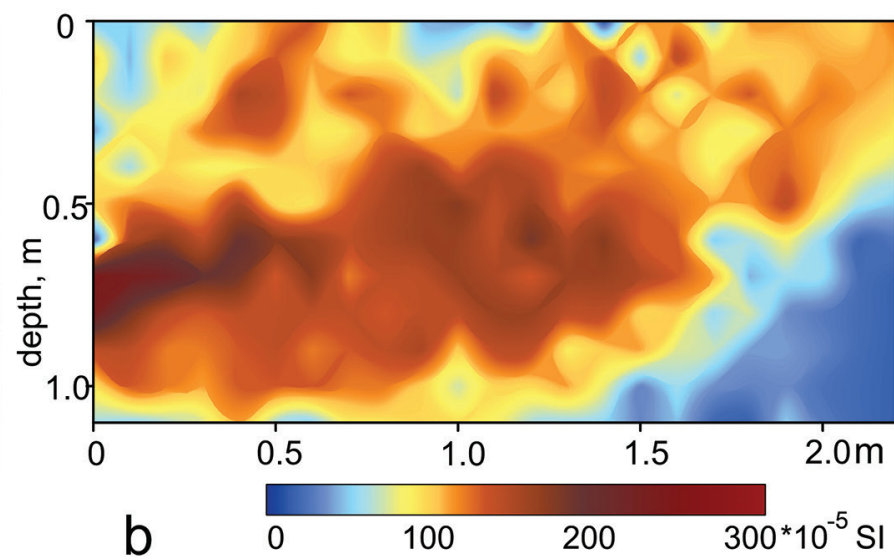

Figure 7. Western wall of the excavation: a: Photograph of the utility pit; b: Result of the magnetic susceptibility measurements.

utility pit and the well, a magnetic susceptibility survey was carried out. Figures 6 and 7 clearly show that the soils filling the pit and well differ from the subsoil, both in colour and in physical properties. The magnetic susceptibility in the pit and well varies from 0.0012 to 0.0030 SI units, the average value being 0.0016 SI units. The bottom filling of the well (silty soil of a grey-green hue) has reduced properties from 0.0008 to 0.0010 SI. In the surrounding subsoil, the values are an order of magnitude less and do not exceed 0.0002 SI units. Due to the contrast of magnetic susceptibility above the well and the pit, anomalies with an intensity of 12-15 nT are observed. The well and the pit stood open for a long time. This can be clearly seen from the fillings in the upper parts, both in their colour and magnetic properties. In the lower part of the utility pit, the magnetic properties are evenly distributed. In the well, the greatest values of magnetic properties are observed along the edges, which indicates that during construction the edges of the wells were reinforced with some kind of special soil.

Hence, studies at the Konoplyanka 1 excavation confirmed the reliability of the reconstructed settlement plan based on magnetic survey, and made it possible to determine the magnetic susceptibility inside the utility pit and the ancient well.

\section{GPR survey of the wells}

For the excavation at the unfortified settlement of Konoplyanka 2, archaeologists chose a site with four local magnetic anomalies (Figures $2 \mathrm{~b}$ and $8 \mathrm{a}$ ). The floor of a rectangular house with a size of $24 \times 9.5 \mathrm{~m}$ was excavated to a depth of $0.6 \mathrm{~m}$ (Koryakova et al., 2020). In its central part, four wells were found, located in a chain along the long axis of the dwelling, and a small pit was found near the western wall (Figures $8 \mathrm{~b}$ and $8 \mathrm{c}$ ). A small part of well 5 was found in the southwest corner outside the end wall of the house. The epicentres of the magnetic anomalies coincided with the centres of the wells and pits (Figure 8).

In the 2019 field season, at the excavation level $-0.6 \mathrm{~m}$ from the modern surface, geophysical work was carried out, the purpose of which was to study the wells using the GPR

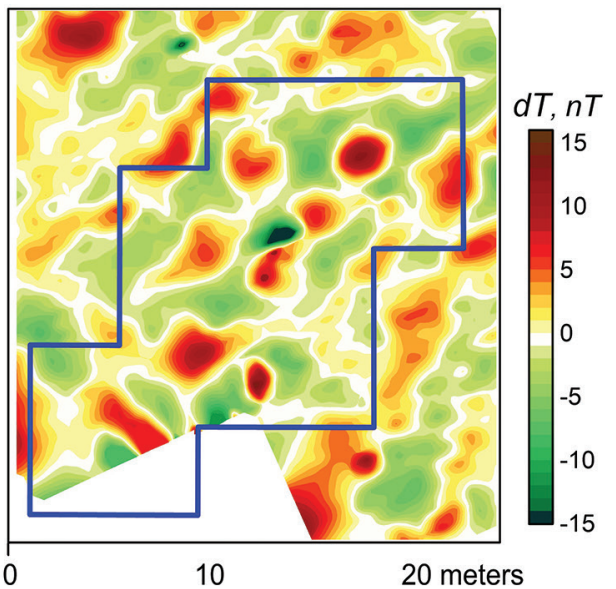

a

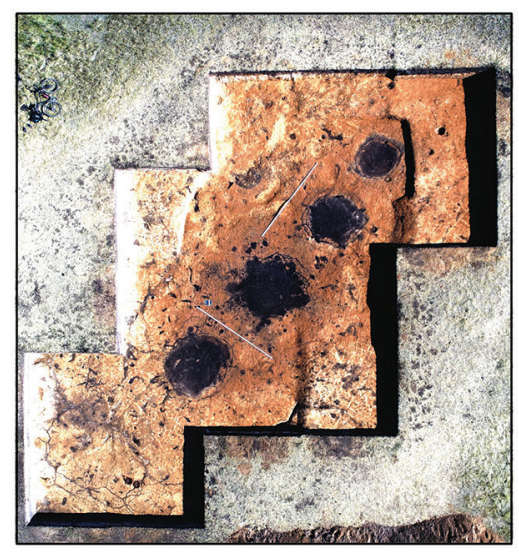

b

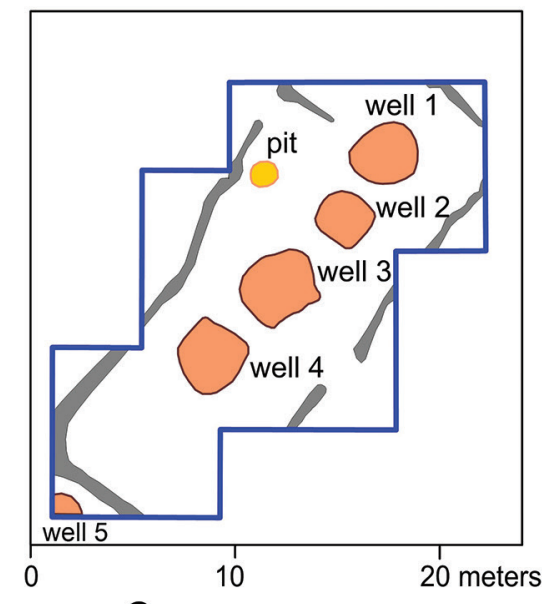

C

Figure 8. Excavation at the settlement of Konoplyanka 2: a: Part of a magnetic map; b: Photograph; c: Plan; after Koryakova et al. (2020). 


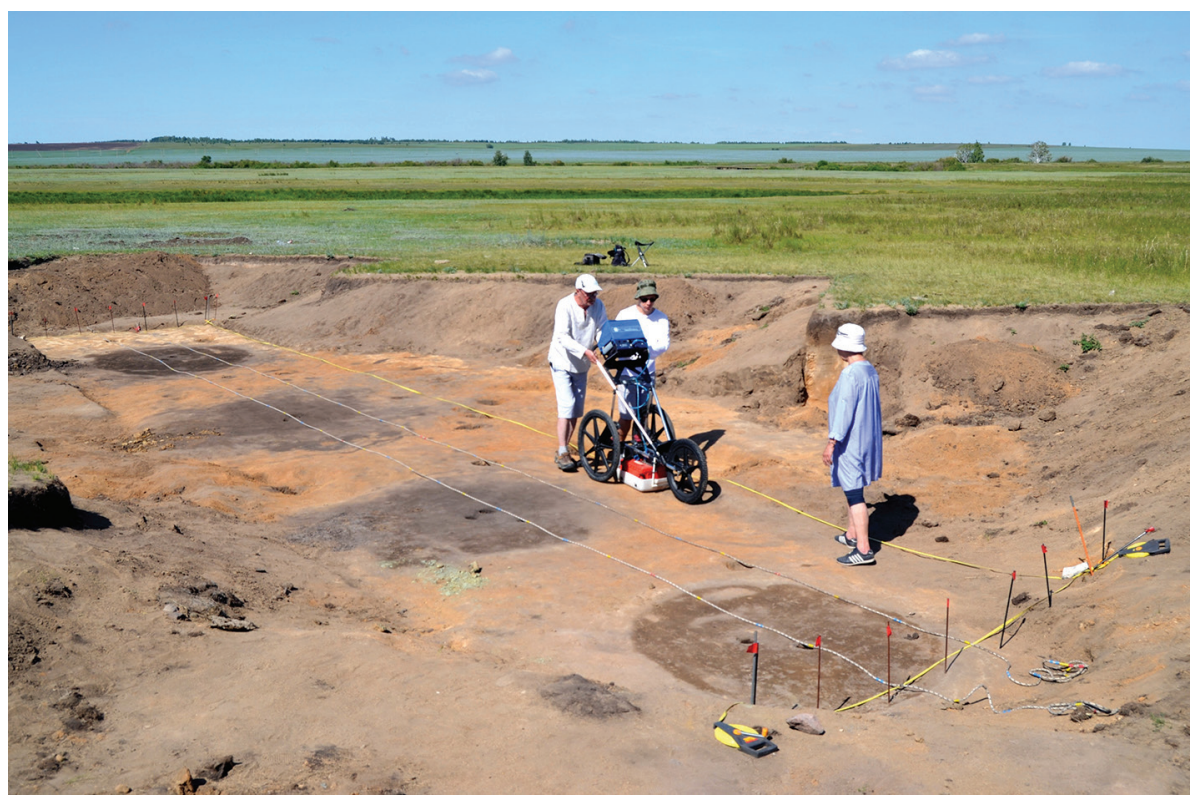

Figure 9. GPR survey of the wells.

method before digging them. On the surface, the diameters of the wells reached 2-2.5 m. The depth of the wells could vary from 2 to 4 metres. The GPR survey was carried out by the SIR-3000 along 6 parallel $(270 \mathrm{MHz})$ profiles with a length of 15 metres. The distance between the profiles was $0.5 \mathrm{~m}$. (Figure 9).

Since at present the wells are covered with practically the same soils (loams) of which the subsoil is composed, it was not expected that there would be a significant contrast in physical properties between them and that during the survey it would be possible to obtain a clear picture of radio wave reflections from the walls of the wells. On the other hand, it was expected that a good contrast of electrical properties exists between the subsoil and the soil with which the walls of the wells were reinforced. Indeed, this contrast in magnetic properties was what was found in the well of the Konoplyanka 1 house.

In addition, at depth, the walls of the wells become almost vertical and this is a blind zone for the GPR. Therefore, we performed measurements with a set of antennae with centre frequencies of 400, 270 and $100 \mathrm{MHz}$. After analysing the obtained sections for various frequencies of electromagnetic waves, the survey carried out with a $270 \mathrm{MHz}$ antenna turned out to be the most effective. Measurements at $400 \mathrm{MHz}$ are shallow. For the studied soils, the vertical resolution is the first few centimetres; therefore, reflections from small irregularities form numerous noises on the section. And for an antenna with a frequency of $100 \mathrm{MHz}$ in this environment, the vertical resolution is greater than 1 metre and the reflective boundaries from the edges of the wells are simply not visible in the sections.

Figure 10 shows the results for the central profile obtained with a $270 \mathrm{MHz}$ antenna. In the section, reflections from the walls of the wells are highlighted in red. The primary and repeated reflections of waves from the inclined walls of the well form a characteristic X-pattern (or "butterfly") on the radargram (Conyers, 2016). This picture of reflections was most clearly manifested for well number 4. After processing and interpolation of reflections from the walls of the wells along all profiles, images of the boundaries of

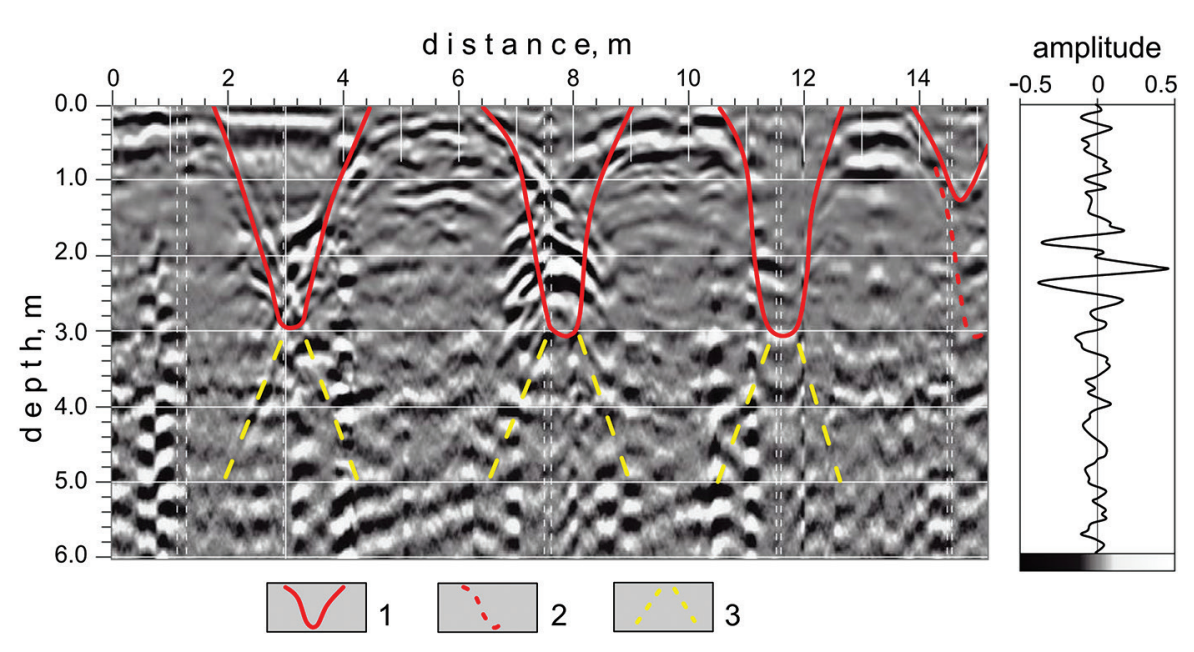

Figure 10. Radargram along the central profile with a $270 \mathrm{MHz}$ antenna. 1 - wall of well; 2 - the assumed boundary of well 4; 3 - secondary reflections from the well's wall. 
Figure 11. Result of GPR survey of wells: a: 3D format; b: Plan.

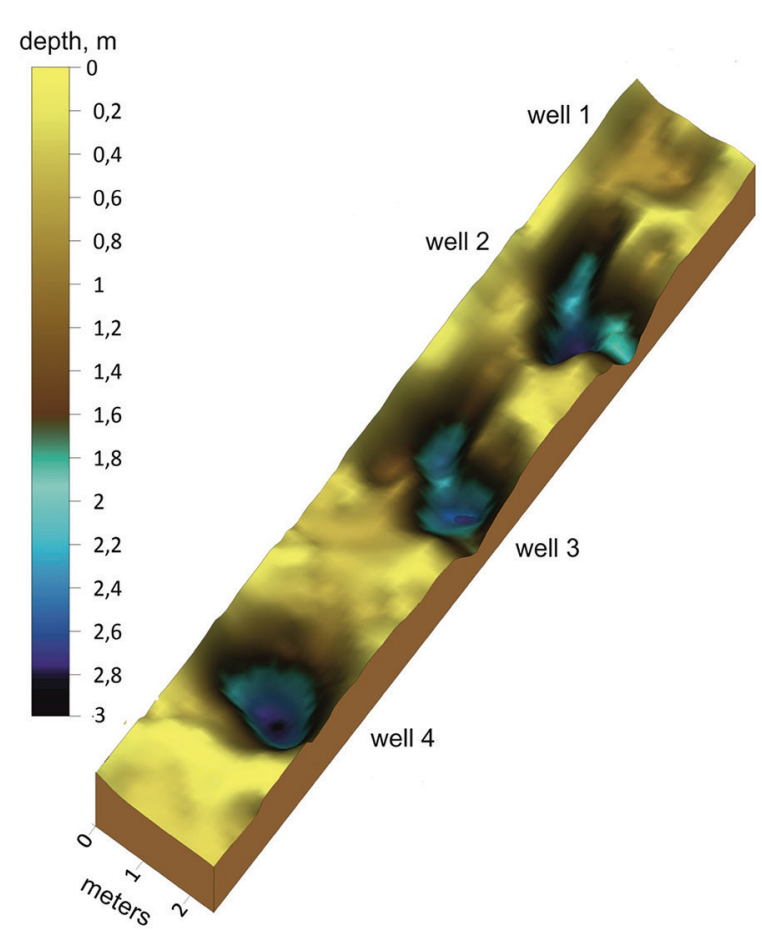

all wells in plan and their three-dimensional view were built (Figure 11).

\section{Discussion of the results of the study of wells}

The depth according to the GPR data for wells 2, 3 and 4 from the survey surface was 2.9-3.1 m, with an estimation error of $\pm 0.3 \mathrm{~m}$. Note the peculiarity of well number 3 , at depth the well shaft is not in the centre, but is displaced relative to the top mouth to the eastern edge. The size of the excavation limited the length of the radar survey lines, and therefore only the southern edge was measured for well number 1 . From the well mouth to its depth, stable reflections from the walls of the well can be traced only to the marks of 1-1.2 m. It is possible that below this depth the well has vertical walls and they are not visible on the radargram. It can only be noted that there are reflective platforms under the central part of the well at depths of more than 2 and 3 metres (Figure 10).

A feature of the "cultural layer" inside the wells was the presence of intense reflections on the radargrams. Such disturbances were most pronounced in well number 3 . The section shows that at a depth of more than $1.2 \mathrm{~m}$, the wave pattern is significantly distorted by numerous reflections in the form of hyperbolas, which indicates the presence of large inhomogeneities inside this well (blocks of denser soil, stones, ceramics, coal, etc.).

Excavations of two wells confirmed the results of geophysical studies (Koryakova et al., 2020). The depth of the well number 3 was $3.17 \mathrm{~m}$, and in the case of the well number 4 it was $3.03 \mathrm{~m}$. It was found that well number 3 has an asymmetric shape, its bottom is displaced relative to the mouth to the eastern edge. Filling was recorded along the periphery of both features between the shafts of the wells and the subsoil. It consists of yellow clay as well as yellow and light brown sand, and was used to strengthen the walls of the shaft and protect the formwork. Remnants of two types of wooden formwork were found in the wells: wattle and board. Two construction phases have been identified. The first is associated with the population of the Srubnaya culture, and the second with the population of the Cherkaskul culture. Radiocarbon analysis showed that the settlement functioned from the $18^{\text {th }}$ to the $16^{\text {th }}$ century $\mathrm{BC}$.

\section{Conclusion}

The comparison of geophysical and archaeological results, both at the fortified settlement of Konoplyanka $1\left(20^{\text {th }}-19^{\text {th }}\right.$ centuries BC) and at the open village of Konoplyanka 2 $\left(18^{\text {th }}-16^{\text {th }}\right.$ centuries $\left.\mathrm{BC}\right)$, showed that with the help of magnetic maps it was possible to reconstruct plans of ancient settlements. Intense local magnetic anomalies inside dwellings made it possible to localise wells and utility pits.

Geophysical studies carried out on the wells revealed that the material with which the edges of the wells were reinforced has not only high magnetization properties, but also differs in its electrical properties from the subsoil. Therefore, intense magnetic anomalies are observed above the wells, and the boundaries of features are confidently determined on radargrams. As a result of the GPR survey of four wells, their 
depths and structural features were determined. Excavations of two wells fully confirmed these results.

\section{Acknowledgments}

Our studies of Bronze Age settlements in the Southern Urals were carried out in close cooperation with a team of archaeologists from the Institute of History and Archaeology of the Ural Branch of the Russian Academy of Sciences. We express our gratitude to L.N. Koryakova, S.V. Sharapova and S.E. Panteleeva, under whose leadership the excavations were carried out in these settlements.

We are grateful to Dale Bradford and Elena Nikolaeva who edited our English text.

\section{References}

ASPINAL, A. GAFFNEY, C., SCHMIDT, A., 2008. Magnetometry for Archaeologists, Lanham, Maryland: Altamira Press.

CONYERS, L.B., 2016. Ground-penetrating Radar for Geoarchaeology. Analytical Methods in Earth and Environmental Science. New York: Wiley Publishing.

BAKHSHIEV, I.I., NOSKEVICH, V.V., NASRETDINOV, R.R., 2018. Geophysical and remote studies of the Ulak-1 fortified settlement of the Bronze age in Bashkir Trans-Urals: the correlation of the obtained data with the results of the archaeological excavations. Povolzhskaya Arkheologiya, 3(25), 30-44.

EPIMAKHOV, A.V., BERSENEVA, N.A., FEDOROVA, N.V., NOSKEVICH, V.V., 2016. Geophysics and archaeology of Bronze Age settlements - A case study from Kamennyi Ambar fortified settlement (South Urals). In: Proceedings 22 $2^{\text {nd }}$ European Meeting of Environmental and Engineering Geophysics. Near Surface Geoscience 2016, September 2016. Barcelona: European Association of Geoscientists and Engineers. DOI:10.3997/2214-4609.201602029.

EPIMAKHOV, A.V., PANTELEYEVA, S.E., KORYAKOVA, L.N., 2020. Wells as a source of cultural and chronological information: The case of Kamennyi Ambar, Southern Trans-Urals. Archaeology Ethnology and Anthropology of Eurasia, 48(4), 95-105. DOI: 10.17746/15630110.2020.48.4.095-105.

FASSBINDER, J.W.E., 2015. Seeing beneath the farmland, steppe and desert soil: magnetic prospecting and soil magnetism. Journal of Archaeological Science, 56, 85-95 DOI:10.1016/j.jas.2015.02.023.

FEDOROVA, N.V., NOSKEVICH, V.V., IVANCHENKO, V.S., BEBNEV, A.S., MALIKOV, A.V., 2014. A magnetic survey of the Bronze Age archaeological settlements in the South Urals. Geophysical Research, 15(3), 24-37.

FEDOROVA, N.V., NOSKEVICH, V.V., MOLCHANOV, I.V., 2018. Results of geophysical studies of the Bronze Age settlement Konoplyanka-2 (South Ural). Uralskiy geofizicheskiy vestnik, 2, 61-66. DOI: 10.25698 / UGV.2018.2.8.61.

FINKELSHTEYN, M.I., KUTEV, V.A., ZOLOTAREV, V.P., 1986. The use of radar subsurface sounding in engineering geology. Moscow: Nedra Publishing.

FORNASIER, J., KRAUSE, R., KORJAKOVA, L.N., STOBBE, A., RUHL, L., SCHNEIDER, H., THIEMEEYER, H., PETERS, S., EPIMAKHOV, A.V., SHARAPOVA, S.V., PANTELEEVA, S.E., MOLCANOV,
I.V., BERSENEVA, N.A., PATZELT, A., NOSKEVICH, V.V., 2014. Architektur, Wirtschaft und Landschaft der Bronzezeitlichen Siedlungen am Nordrand der Eurasischen Steppe im Trans-Ural (Russische Föderation). Eurasia Antiqua, 20, 229-272.

HANKS, B.K., CHECHUSHKOV, I.V., DUNAN, R.K., PITMAN, D., MUZHICH, B., MEDARICH, I., MORI, M., 2013. Recent results and prospects of research of the ancient Ustye settlement area and the lower Toguzak river valley. In: N.B. Vinogradov and A.V. Epimakhov, eds. Ancient Ustye: A fortified Bronze Age settlement in the South TransUrals. Chelyabinsk: Abris, pp. 393-416.

GENING, V.F., ZDANOVICH, G.B., GENING, V.V., 1992. Sintashta: Archaeological sites of the Aryan tribes of the Urals-Kazakhstan steppes. Chelyabinsk: South Urals Publishing.

GSSI, 2008. SIR-3000, RADAN, Geophysical Survey Systems, Inc. Salem. NH, USA. Available from: http://www.geophysical.com/software.

JORDANOVA, N., 2016. Soil magnetism: Applications in Pedology, Environmental Science and Agriculture, Elsevier: Academic Press.

KORYAKOVA, L.N., KRAUSE, R., SHARAPOVA, S.V., FEDOROVA, N.V., KOSINTSEV, P.A., ZAYKOV V.V., ANKUSHEV, M.N., 2018. Enclosed settlements of the Karagaily-Ayat river basin through the prism of the multidisciplinary approach. History of Science and Engineering, $1,22-36$.

KORYAKOVA, L.N., PANTELEYEVA, S.E., 2019. Wells of the fortified settlement Kamennyi Ambar. Uralskiy istoricheskiy vestnik, 1(62), 17-27. DOI: 10.30759/1728-9718-2019-1(62)-17-27

KORYAKOVA L.N., KRAUSE R., PANTELEEVA S.E., STOLYARCHIK E., BULAKOVA E.A., SOLDATKIN N.V., RASSADNIKOV A.YU., MOLCHANOVA V.V., ANKUSHEV M.N., MOLCHANOV I.V., YAKIMOV A.S., FEDOROVA N.V., NOSKEVICH V.V., 2020. Settlement Konoplyanka 2 in the Southern Trans-Urals: preliminary research results. Uralskiy istoricheskiy vestnik, 4(69), 51-63. DOI: 10.30759 / 1728-9718-2020-4 (69) -51-63.

MERRONY, C., HANKS, B., DOONAN, R., 2009. Seeking the Process: The Application of Geophysical Survey on some Early Mining and Metalworking Sites. Studies in honour of Barbara S. Ottaway. In: Universitatsforschungen zur prahistorischen Archaologie. Bonn: Metalsand Societies, pp. 421-430.

NOSKEVICH, V.V., FEDOROVA, N.V., 2013. Remote sensing methods of survey. In: R. Krause and L.N. Koryakova, eds. Multidisciplinary investigations of the Bronze Age settlements in the Southern Trans-Urals (Russia). Bonn: Dr. Rudolf Habelt Publishing, pp. 67-84.

NOSKEVICH, V., FEDOROVA, N., 2020. Geophysical investigations of the Bronze Age Andreevskoye settlement in the Southern TransUrals (Russia). Interdisciplinaria Archaeologica, Natural Sciences in Archaeology, 11(2), 139-147. DOI: 10.24916/iansa.2020.2.1.

PUNEGOV, B.N., 2009. Micromagnetic survey during archaeological research (on the example of Arkaim). Uralskiy geofizicheskiy vestnik, 1, $50-58$.

SCOLlAR, I., TABBAGH, A., HESSE, A., HERZOG, I., 1990. Archaeological prospecting and remote sensing. Cambridge and New York: Cambridge University Press.

SHARAPOVA, S.V., KRAUSE, R., MOLCHANOV, I.V., STOBBE, A., SOLDATKIN, N.V., 2014. Multidisciplinary investigations of Konoplyanka settlement in the Southern Trans-Urals: preliminary results. Vestnik Novosibirskogo gosudarstvennogo universiteta. Seriya: Istoriya, filologiya, 13(3), 101-109.

TARASOV, Y.V., 1983. Report on archaeological exploration in the Kartaly district of the Chelyabinsk region in 1982., Chelyabinsk: Arkhiv IA RAN. TIBELIUS, V.Y., 1995. Results of geophysical research on Arkaim. In: Russia and the East: Problems of interaction. Chelyabinsk: CSU, pp. 184-193.

ZDANOVICH, G.B., BATANINA, I.M., 2007. Arkaim - country of towns. Space and images. Chelyabinsk: Krokus Publishing. 